\title{
PENGARUH GROWTH OPPORTUNITY, CORPORATE SOCIAL RESPONSIBILITY, GOOD CORPORATE GOVERNANCE DAN KEPUTUSAN INVESTASI TERHADAP NILAI PERUSAHAAN (Studi pada Perusahaan Sektor Property, Real Estate \& Building Construction Periode 2013-2017)
}

\author{
Muhammad Fariz Wiranoto \\ Universitas Negeri Surabaya \\ farizwiranoto@gmail.com
}

\begin{abstract}
This study analyses influence growth opportunities, corporate social responsibility, managerial ownership, committee audit, and investment decision to the company property, real estate \& buildings construction sector from 2013 to 2017. This research is quantitative, employing purposive sampling and obtaining samples from 49 companies. Technique analysis used is multiple regression by SPSS. The research results show that growth opportunities, corporate social responsibility, managerial ownership, committee audit, and investment decision have a significant influence on the company. Partial it shows that: 1) growth opportunities have a positive impact significantly on the company, based on the results of data analysis, the companies experiencing a decline and increasing growth opportunity are also proven to be followed by an increase and decrease in firm value or (PER). 2) corporate social responsibility does not have significantly on the company. Based on data analysis from 40 sample companies, only one company presents more than 50\% GRI information. 3) Managerial ownership does not have significantly on the company. From the data analysis results, most companies do not have managerial ownership companies. 4) The audit committee has no significant effect on the company's value because an audit committee in the company is seen only as a fulfilment of the government's regulatory obligations. The audit committee has not carried out its obligations in a manner maximum. 5) Investment decisions significantly do not affect the company's value because most companies have not implemented meaningful investment decisions, as evidenced by a TAG value of less than 1.
\end{abstract}

Keywords: CSR; GCG; growth; investment; value

\section{PENDAHULUAN}

Tujuan utama suatu perusahaan adalah memperoleh laba, sedangkan untuk tujuan lain perusahaan yang go public yaitu memberikan kemakmuran bagi pemilik yaitu para pemegang saham dan stakeholder yang menanamkan modalnya di suatu perusahaan (Hermuningsih, 2012). Suatu perusahaan yang telah memiliki laba dan telah memberikan kemakmuran pada para pemegang saham maka seorang investor akan tertarik untuk menanamkan modalnya, apabila kemungkinan untuk mendapatkan keuntungan yang lebih besar atas pengembalian modal dan laba dari perusahaan yang diinvestasikannya, keuntungan tersebut dapat berupa capital gain dan juga deviden sebagai bentuk dari pembagian keuntungan perusahaan yang diberikan kepada investor atau pemilik saham (Martini, 2014).

Pertumbuhan nilai suatu perusahaan bisa diperoleh jika shareholder dan stakeholder mampu bekerjasama dalam menentukan kebijakan yang tepat di suatu perusahaan dalam memaksimalkan modal yang dimiliki perusahaan tersebut, kebijakan tersebut dapat berjalan maksimal jika suatu perusahaan mampu menerapkan tata kelola perusahaannya dengan baik (Thaharah \& Asyik, 2016). Praktiknya untuk menyatukan kepentingan kedua belah pihak yang memiliki perselisihan dalam perusahaan sering kali menimbulkan suatu masalah agensi atau agency problem, adanya suatu permasalahan tersebut akan berdampak pada munculnya pemisah dari pihak kepemilikan serta adanya masalah dari sisi manajemen dan pemilik yang mengakibatkan suatu perusahaan mengalami perpecahan dalam struktur organisasinya yang bisa menimbulkan seorang investor untuk menarik modalnya di suatu perusahaan tersebut (Agustine, 2014). 
Muhammad Fariz Wiranoto. Pengaruh Growth Opportunity, Corporate Social Responsibility, Good Corporate Governance dan Keputusan Investasi terhadap Nilai Perusahaan (Studi pada Perusahaan Sektor Property, Real Estate \& Building Construction Periode 2013-2017)

Tabel 1

RESEARCH GAP

\begin{tabular}{|c|c|c|c|c|c|}
\hline Nama & $\begin{array}{c}\text { Growth } \\
\text { Opportunity }\end{array}$ & CSR & $\begin{array}{c}\text { Kepemilikan } \\
\text { Manajerial }\end{array}$ & $\begin{array}{c}\text { Komite } \\
\text { Audit }\end{array}$ & $\begin{array}{c}\text { Keputusan } \\
\text { Investasi }\end{array}$ \\
\hline Achmad dan & & & & & \\
\hline Amanah (2014) & & & & & \\
\hline Agustine (2014) & & NS & - & & \\
\hline $\begin{array}{l}\text { Hermuningsih } \\
\text { (2013) }\end{array}$ & + & & & & \\
\hline Ananda dan & + & & & & \\
\hline Anggraini (2013) & & & & + & \\
\hline $\begin{array}{l}\text { Antari dan dana } \\
(2012)\end{array}$ & & & - & & \\
\hline Apriada dan & & & & & \\
\hline Suardikha (2016) & & & + & & \\
\hline Bidhari et al (2013) & & + & & & \\
\hline Nisa (2015) & & & & & + \\
\hline Onasis dan Robin & & & NS & + & \\
\hline $\begin{array}{l}\text { Obradovich dan Gill } \\
\text { (2012) }\end{array}$ & & & NS & + & \\
\hline $\begin{array}{l}\text { Purwohandoko } \\
2017\end{array}$ & NS & & & & \\
\hline Putu et al (2014) & & + & & & \\
\hline $\begin{array}{l}\text { Rakhimsyah dan } \\
\text { Gunawan (2011) }\end{array}$ & & & & & + \\
\hline Safitri dan & & & & & \\
\hline Wahyuati (2015) & & & & & + \\
\hline Rizqia et al (2013) & & & + & & \\
\hline Setiani (2013) & & & & & NS \\
\hline Setyawan (2016) & & NS & & NS & \\
\hline $\begin{array}{l}\text { Thaharah dan Asyik } \\
\text { (2016) }\end{array}$ & & & NS & + & \\
\hline $\begin{array}{l}\text { Tjia dan Setiawati } \\
(2012)\end{array}$ & & + & & & \\
\hline $\begin{array}{l}\text { Wardoyo dan } \\
\text { Veronica (2013) }\end{array}$ & & NS & & NS & \\
\hline
\end{tabular}

Sumber: Diolah penulis

Purwohandoko (2017) mengatakan bahwa pertumbuhan tidak berpengaruh dengan nilai perusahaan dikarenakan perusahaan tidak membutuhkan banyak dana untuk memenuhi pertumbuhan investasi. Perusahaan di Indonesia cenderung memilih menggunakan utang daripada investasi, sehingga pertumbuhan perusahaan tidak berpengaruh terhadap nilai perusahaan. Berbeda dengan Hermuningsih (2013) dan Ananda \& Nugraha (2016), bahwa pertumbuhan berpengaruh positif terhadap nilai perusahaan perusahaan karena dengan tingkat pertumbuhan yang tinggi sebaiknya menggunakan ekuitas sebagai sumber pembiayaan untuk menghindari biaya keagenan (agency cost) antara pemegang saham dengan manajemen perusahaan.

Menurut Putu et al (2014), CSR berpengaruh positif terhadap nilai perusahaan hal ini menunjukkan perusahaan manufaktur menyadari manfaat yang diterima dari penerapan praktik tanggung jawab sosial dan pengungkapan Integrasi secara luas. Salah satu contoh adalah untuk meningkatkan citra perusahaan, yang dalam waktu lama akan meningkatkan reputasi perusahaan yang berdampak pada peningkatan nilai Perusahaan. Hasil tersebut bertolak belakang dengan penelitian Setyawan (2016) dan Agustine (2014) yang menyatakan CSR tidak berpengaruh terhadap nilai perusahaan hal ini diakibatkan karena investor di Indonesia cenderung membeli dan menjual saham tanpa memerhatikan keberlangsungan hidup perusahaan dalam jangka panjang. 
Praktik Good Corporate Govermance (GCG) dalam suatu perusahaan yang memberikan tekanan terhadap kepemilikan manajerial dan komite audit akan meningkatkan kinerja yang diharapkan oleh para investor. Proporsi pemegang saham dari pihak manajemen dalam menjalankan perusahaan serta pengambilan keputusan perusahaan oleh direktur dan komisaris disebut sebagai kepemilikan manajerial (Thaharah \& Asyik, 2016). Apriada \& Suardikha (2016) menyatakan kepemilikan manajerial berpengaruh positif terhadap nilai perusahaan besarnya kepemilikan manajerial mengakibatkan semakin kuatnya kontrol eksternal perusahaan. Adanya kepemilikan manajerial akan mendorong tingkat pengawasan yang lebih optimal terhadap kualitas perusahaan. Tujuan perusahaan tercapai apabila kinerja perusahaan mampu mengoptimalkan nilai perusahaan. Hasil ini berbeda dengan Agustine (2014) dan Antari \& Dana (2012), bahwa manajerial berpengaruh negatif terhadap nilai perusahaan, sedangkan Onasis \& Robin (2016) menyatakan bahwa kepemilikan manajerial tidak berpengaruh terhadap nilai perusahaan.

Menurut Gill \& Obradovich (2012), jumlah rapat komite audit menunjukkan keaktifan komite audit dalam melaksanakan dan mengendalikan jalannya tata kelola perusahaan yang baik, semakin banyak frekuensi rapat mencerminkan semakin aktifnya komite audit dalam melakukan pengendalian tata kelola perusahaan dalam meningkatkan nilai perusahaan. Onasis \& Robin (2016) berpendapat bahwa komite audit berpengaruh positif terhadap nilai perusahaan berdeda dengan Setyawan (2016) berpendapat bahwa komite audit tidak berpengaruh terhadap nilai perusahaan. Menurut Setyawan (2016), hal ini dimungkinkan karena perusahaan hanya berlaku untuk memenuhi GCG formal, untuk keberadaan komite audit tidak menunjukkan perbaikan kinerja perusahaan yang berpengaruh pada nilai perusahaan.

Keputusan investasi merupakan keputusan yang dikeluarkan perusahaan terkait dengan kegiatan perusahaan untuk melepaskan dana pada saat sekarang dengan harapan untuk menghasilkan arus dana masa mendatang dengan jumlah yang lebih besar dari yang dilepaskan pada saat investasi awal, sehingga harapan perusahaan untuk selalu tumbuh dan berkembang akan semakin jelas dan terencana (Nisa, 2015). Rakhimsyah \& Gunawan (2011) menemukan bahwa keputusan investasi berpengaruh positif terhadap nilai perusahaan. Penelitian ini sejalan dengan Nisa (2015) dan Safitri \& Wahyuati (2015), sedangkan Setiani (2013) berpendapat bahwa keputusan investasi tidak berpengaruh terhadap keputusan investasi.

Berdasarkan data Price Earning Ratio (PER) sektoral selama periode 2013 - 2017, menunjukkan bahwa price earning ratio perusahaan berfluktuatif dan variatif dari tahun ke tahun ditunjukkan pada Tabel 2.

\section{Tabel 2}

RASIO PRICE EARNING RATIO SEKTORAL PERUSAHAAN DI INDONESIA PERIODE $2013-2017$

\begin{tabular}{lccccc}
\hline \multirow{2}{*}{ SECTOR } & \multicolumn{5}{c}{ PER } \\
\cline { 2 - 6 } & $\mathbf{2 0 1 3}$ & $\mathbf{2 0 1 4}$ & $\mathbf{2 0 1 5}$ & $\mathbf{2 0 1 6}$ & $\mathbf{2 0 1 7}$ \\
\hline Agiculture & 22.22 & 19,34 & $-1,21$ & 19,38 & 19,38 \\
Mining & 14,43 & 2,90 & 7.77 & 11,39 & 11,39 \\
Basic Industry and Chemicals & 15,28 & 16,60 & 5,32 & 14,32 & 14,32 \\
Miscellaneous Industry & 13,74 & 14,44 & 3,24 & 13,54 & 13,54 \\
Consumer Goods Industry & 23,51 & 24,22 & 17,69 & 18,77 & 18,77 \\
Property, Real Estate and Building Construction & 15,90 & 16,29 & 18,09 & 27,90 & 27,90 \\
Infrastucture, Utilities and Transportation & 21,54 & 17,61 & 14,49 & 10,04 & 10,04 \\
Finance & 16,93 & 28,71 & 22,08 & 20,63 & 20,63 \\
Trade, Service and Investment & 17,61 & 21,55 & 12,49 & 19,49 & 19,49 \\
\hline
\end{tabular}

Sumber: Bursa Efek Indonesia/www.idx.co.id (Diolah, 2018)

Berdasarkan Tabel 2, rasio Price Earning Ratio (PER) sektoral selama periode 2013-2017, menunjukkan bahwa price earning ratio perusahaan berfluktuatif dan variatif dari tahun ke tahun. 
Muhammad Fariz Wiranoto. Pengaruh Growth Opportunity, Corporate Social Responsibility, Good Corporate Governance dan Keputusan Investasi terhadap Nilai Perusahaan (Studi pada Perusahaan Sektor Property, Real Estate \& Building Construction Periode 2013-2017)

Beberapa sektor yang dapat diamati mayoritas penurunan namun terdapat perbedaan mencolok pada sektor Property, Real Estate \& Building Construction yang mengalami kestabilan pada tahun 2017 sampai pada tahun 2016 kemudian mengalami kenaikan 3 tahun berturut-turut pada tahun 2015 sebesar 9,81\% lebih besar dibandingkan tahun sebelumnya 2014 sebesar 1,8\% dan pada tahun 2013 sebesar $0,39 \%$.

Besarnya price earning ratio selama tiga tahun berturut-turut juga mengindikasikan besarnya nilai perusahaan, terkait demikian dipilih sektor Property, Real Estate \& Building Construction untuk dijadikan objek penelitian, mengingat hanya sektor inilah yang menunjukkan price earning ratio dengan pertumbuhan yang signifikan selama tiga tahun berturut-turut dibandingkan sektor lain di Bursa Efek Indonesia pada tahun 2013-2017. Nilai Perusahaan dipengaruhi beberapa faktor yang beragam yaitu growth opportunity, CSR, kepemilikan manajerial, komite audit, dan keputusan investasi sebagai variabel independen dalam penelitian ini (Adhitya Ananda \& Nugraha Ardana P, 2018; Agustine, 2014; Anggraini, 2013; Antari \& Dana, 2013; Kadek \& Made Sadha, 2016; Robin Kristie Onasis, 2016). Tujuan dari penelitian ini untuk menganalisis pengaruh Growth Opportunity, Corporate Social Responsibility, Kepemilikan Manajerial, Komite Audit, dan Keputusan Investasi terhadap Nilai Perusahaan pada perusahaan sektor Property, Real Estate \& Building Construction periode 2013-2017.

\section{KAJIAN PUSTAKA DAN PENGEMBANGAN HIPOTESIS}

\section{Signaling Theory}

Menurut Hartono (2008:529) informasi perusahaan yang dipublikasikan akan memberikan signal bagi investor dalam pengambilan keputusan investasi, jika bernilai positif maka diharapkan pasar akan bereaksi pada waktu pengumuman tersebut. Signaling Theory dalam penelitian ini menjelaskan hubungan variabel growth opportunity dengan keputusan investasi.

\section{Agency Theory}

Hubungan keagenan dikatakan telah terjadi ketika suatu kontrak antara seseorang atau lebih, seorang prinsipal, seorang agen, dan orang lainnya untuk memberikan jasa demi kepentingan prinsipal dalam suatu perusahaan termasuk melibatkan kepentingan adanya pemberian delegasi kekuasaan pengambilan keputusan kepada agen (Anggraini, 2013). Teori keagenan dalam penelitian ini digunakan untuk menjelaskan pengaruh kepemilikan manajerial dan komite audit terhadap nilai perusahaan.

\section{Stakeholders Theory}

Teori stakeholder mengatakan bahwa perusahaan bukan satu-satunya entitas yang beroperasi untuk kepentingannya sendiri, tetapi harus memberikan manfaat bagi para pemangku kepentingannya. Adanya suatu perusahaan dipengaruhi oleh dukungan para pemangku kepentingan terhadap perusahaan (Setyawan, 2016). Penelitian ini Stakeholders Theory digunakan sebagai landasan pengungkapan CSR terhadap nilai perusahaan.

\section{Legitimacy Theory}

Menurut Tjia \& Setiawati (2012) teori legitimasi perusahaan memiliki kontrak dengan masyarakat untuk melakukan kegiatannya berdasarkan keadilan dan perusahaan berusaha menanggapi berbagai kelompok kepentingan untuk mendapat legitimasi dari kelompok tersebut. Legitimasi teori digunakan untuk menjelaskan landasan CSR terhadap nilai perusahaan.

\section{Nilai Perusahaan}

Nilai perusahaan dianggap seperti pandangan atau penilaian publik dan juga investor terkait dengan maksimalisasi pencapaian perusahaan yang dilihat dari naik turunnya harga saham (Setiani, 2013). Harga saham menjadi gambaran bagi perusahaan, karena perusahaan akan dianggap memiliki nilai perusahaan yang baik atau tinggi jika mempunyai kestabilan harga saham serta terus menunjukkan 
peningkatan. Nilai perusahaan diproksikan dengan Price Earning Ratio (PER), dengan rumus (Herawati, 2013):

PER $=\frac{\text { Harga Pasar Perlembar Saham }}{\text { Laba Perlembar Saham }}$

\section{Growth Opportunity}

Growth opportunity dianggap tingkatan dari terjadinya peluang tumbuhnya perusahaan untuk masa akan datang, untuk melihat peluang tersebut perlu diketahui keuntungan dari lembar saham yang dapat dinaikkan melalui leverage (Purwohandoko, 2017). Variabel growth opportunity dalam penelitian ini diproksikan dengan rasio sebagai berikut (Hermuningsih, 2013):

MTBE $=\frac{\text { (Lembar saham beredar } x \text { Harga saham })}{\text { Total ekuitas }}$.

\section{Corporate Social Responbility}

Tanggungjawab sosial atau CSR didefinisikan sebagai bentuk aksi sosial yang nyata dilakukan perusahaan di luar tujuan perusahaan, dan menjadi suatu kewajiban yang harus dilakukan oleh perusahaan dan ditetapkan dengan adanya hukum (Putu et al., 2014). Indeks pengungkapan CSR, dituliskan pada rumus berikut (Veronica \& Wardoyo, 2013):

PS $=\frac{\text { Item yang diungkapkan oleh perusahaan }}{79 \text { Item }}$ X $100 \%$

\section{Good Corporate Governance}

GCG berperan utama di perusahaan, yaitu dalam memberikan kesejahteraan bagi pemegang saham serta sebagai usaha memanfaatkan sumber daya dalam memperoleh laba (Brigham \& Houston, 2010). Untuk mengukur GCG, dapat diproksi dengan rumus sebagai berikut hukum (Agustine, 2014 ; Veronica \& Wardoyo, 2013) :

INSD $=\frac{\text { Jumlah saham yang dimiliki oleh manajemen }}{\text { Jumlah saham yang beredar }}$

Jumlah Komite Audit $=\sum$ Anggota komite audit.

\section{Keputusan Investasi}

Menurut Achmad \& Amanah (2014) keputusan investasi adalah upaya manajemen keuangan perusahaan dalam mencapai tujuan perusahaan dengan aktivitas investasi. Keputusan investasi dapat dilihat dari pertumbuhan aset, yang dapat dirumuskan sebagai berikut (Setiani, 2013) :

$T A G=\frac{\text { Total Aset }_{t}-\text { Total Aset }_{t-1}}{\text { Total Aset }_{t-1}}$

\section{Hubungan antar Variabel}

Growth opportunity dianggap tingkatan dari terjadinya peluang tumbuhnya perusahaan untuk masa akan datang, untuk melihat peluang tersebut perlu diketahui keuntungan dari lembar saham yang dapat dinaikkan melalui leverage (Purwohandoko, 2017). Tumbuhnya perusahaan dengan stabil, akan berkontribusi pada peningkatan arus kas untuk waktu mendatang, serta memiliki potensi pada terjadinya peningkatan profitabilitasnya. Peningkatan profitabilitas akan memberikan dampak pada nilai pasar saham sehingga akan membentuk nilai perusahaan dalam kategori baik (Hermuningsih, 2012). Perusahaan memiliki kemampuan dan peluang untuk melakukan investasi dengan harapan meningkatkan profit perusahaan di masa mendatang sehingga akan dianggap lebih siap dan mampu dalam meningkatkan nilai pemegang saham (Purwohandoko, 2017). Penelitian mengenai growth opportunity pada nilai perusahaan dilakukan Antari \& Dana (2013) dan Hermuningsih (2013) menunjukkan growth opportunity mempunyai dampak pada nilai perusahaan, jika perusahaan mempunyai peluang pertumbuhan tinggi maka nilai perusahaan juga akan semakin maksimal. Hasil yang berbeda dikemukakan Purwohandoko (2017) di mana mengatakan growth opportunity tidak memberikan dampak pada naik turunnya nilai perusahaan hal ini disebabkan karena para investor kurang mendapatkan sinyal dari perusahaan yang akan ditanami saham sehingga pertumbuhan tidak berdampak di nilai perusahaan. 
Muhammad Fariz Wiranoto. Pengaruh Growth Opportunity, Corporate Social Responsibility, Good Corporate Governance dan Keputusan Investasi terhadap Nilai Perusahaan (Studi pada Perusahaan Sektor Property, Real Estate \& Building Construction Periode 2013-2017)

\section{H1 : Growth opportunity berpengaruh terhadap nilai perusahaan}

Tanggungjawab sosial atau CSR didefinisikan sebagai bentuk aksi sosial yang nyata dilakukan perusahaan di luar tujuan perusahaan, dan menjadi suatu kewajiban yang harus dilakukan oleh perusahaan dan ditetapkan dengan adanya hukum (Putu et al., 2014). CSR didefinisikan sebagai aksi yang dilakukan perusahaan sebagai bentuk tanggung jawab sosial di luar tujuan utama perusahaan, adanya pengungkapan CSR juga diharapkan dapat memberikan peningkatan pada citra perusahaan dalam meningkatkan penjualan (Nyoman et al., 2014). Banyak penelitian yang membahas mengenai pengaruh CSR terhadap nilai perusahaan. Bidhari et al (2013) mengemukakan pengaruh positif dari CSR dan nilai perusahaan, hal ini didukung penelitian Nyoman et al (2014). Berdasarkan hasil penelitian Tjia \& Setiawati (2012) menyatakan bahwa CSR masih belum memiliki pengaruh pada peningkatan nilai perusahaan. Penelitian ini didukung oleh hasil penelitian dari Setyawan (2017), serta Agustine (2014) yang tidak juga menemukan pengaruh antara CSR dengan nilai perusahaan.

\section{$\mathrm{H} 2$ : Corporate social responsbility berpengaruh terhadap nilai perusahaan}

Good Corporate Governance (GCG) berperan utama di perusahaan, yaitu dalam memberikan kesejahteraan bagi pemegang saham serta sebagai usaha memanfaatkan sumber daya dalam memperoleh laba (Brigham \& Houston, 2010). Mekanisme tata kelola perusahaan atau corporate governance memiliki kontribusi yang penting dalam perusahaan dapat dilakukan dengan adanya kepemilikan manajerial serta komite audit (Agustine, 2014). GCG berperan penting dalam perusahaan, di mana GCG berperan dalam peningkatan kesejahteraan pemegang saham dan pemaksimalan harta yang dimiliki dalam memperoleh laba (Brigham \& Houston, 2010). Teori keagenan menyatakan bahwa adanya perbedaan tujuan yang ingin dicapai antara prinsipal dan agen, serta adanya pihak pemisah antara kepemilikan dengan pengendalian perusahaan akan memberikan dampak pada perilaku manajer yang mengikuti keinginan prinsipal (Jensen \& Meckling, 1976).

Perusahaan yang memiliki kepemilikan manajerial yang tinggi, memiliki keuntungan dalam mengurangi adanya konflik agensi akibat perilaku manajer untuk meningkatkan keuntungan perusahaan, kondisi tersebut akan membuat manajer lebih objektif dalam pengungkapan informasi umum yang dapat memaksimalkan image perusahaan serta untuk meningkatkan nilai perusahaan (Agustine, 2014). Kadek \& Made Sadha (2016), sebelumnya telah melakukan penelitian yang mendapatkan hasil signifikan positif. Agustine (2014) dan Antari \& Dana (2013) menyatakan kepemilikan manajerial perusahaan memiliki kontribusi yang negatif pada nilai perusahaan.

\section{H3 : Kepemilikan manajerial berpengaruh terhadap nilai perusahaan}

Komite audit dalam suatu perusahaan memiliki posisi membantu dewan komisaris melakukan pengawasan di manajemen perusahaan, pengawasan yang dilakukan pada kualitas laporan keuangan, pengendalian internal perusahaan, serta meningkatkan efektifitas fungsi audit yang diharapkan memiliki kontribusi pada meningkatnya nilai perusahaan (Anggraini, 2013). Dalam penelitian yang dilakukan Anggraini (2013) dan Gill \& Obradovich (2012), diketahui komite audit mampu memberikan kontribusi yang positif pada peningkatan nilai perusahaan. Bertolak belakang dengan penelitian Setyawan (2017) di mana komite audit masih belum dapat menjamin pada baiknya nilai perusahaan, komite audit dalam perusahaan masih sebatas pada pemenuhan regulasi yang ada dan belum sesuai fungsinya dengan maksimal.

\section{H4 : Komite audit berpengaruh terhadap nilai perusahaan}

Keputusan investasi adalah upaya manajemen keuangan perusahaan dalam mencapai tujuan perusahaan dengan aktivitas investasi, adanya kesempatan investasi menjadi nilai perusahaan besar kecilnya tergantung dari pengeluaran yang ditentukan manajemen untuk ke depandengan keputusan investasi yang diambil manajemen diharapkan dapat memberikan keuntungan yang lebih besar (Achmad \& Amanah, 2014). Hasil penelitian dari Nisa (2015), di mana kebijakan investasi yang tepat 
akan berkontribusi positif pada peningkatan nilai perusahaan. Betolak belakang dengan Setiani (2013), keputusan investasi masih belum dapat mencerminkan pada naik turunnya nilai perusahaan.

H5 : Keputusan investasi berpengaruh terhadap nilai perusahaan

\section{METODE PENELITIAN}

Penelitian ini menggunakan penelitian kuantitatif, yaitu penelitian di mana data yang digunakan berupa numerik serta dianalisis dengan analisis statistik. Jenis penelitian ini adalah penelitian kausal. Variabel independen terdiri dari growth opportunity, corporate social responsbility, kepemilikan manajerial, komite audit, dan keputusan investasi, Nilai perusahaan menjadi variabel dependen.

Teknik purpose sampling digunakan sebagai metode pengambilan sampel. Adapun kriteria dalam memilih sampel yaitu perusahaan yang menyajikan laporan keuangan dan tahunan dalam penelitian periode 2013-2017. Berdasarkan teknik purpose sampling diperoleh jumlah sampel 49 perusahaan. Teknik analisis data dilakukan dengan analisis regresi linier berganda, uji asumsi klasik, uji statistik F, uji statistik t dan uji koefisien determinasi $\left(\mathrm{R}^{2}\right)$, dengan persamaan regresi sebagai berikut:

$Y=a+\beta_{1} X_{1}+\beta_{2} X_{2}+\beta_{3} X_{3}+\beta_{4} X_{4}+\beta_{5} X_{5} e$

Keterangan:

$\mathrm{Y} \quad=$ Variabel dependen (Nilai perusahaan)

a $\quad=$ Konstanta

$\beta 1-4=$ Koefisien regresi

$\mathrm{X} 1=$ Growth Opportunity

$\mathrm{X} 2$ = Corporate Social Responsbility

X3 = Kepemilikan Manajerial

$\mathrm{X} 4=$ Komite Audit

$\mathrm{X} 5=$ Keputusan Investasi

e $=$ error

\section{HASIL DAN PEMBAHASAN}

Berikut hasil uji asumsi klasik data dalam penelitian ini:

Tabel 3

HASIL UJI ASUMSI KLASIK

\begin{tabular}{llc}
\hline \multicolumn{1}{c}{ Uji Asumsi Klasik } & \multicolumn{1}{c}{ Perolehan Nilai } & Keterangan \\
\hline Uji Normalitas & Sig. sebelum diobati $0,000<0,05$ & Normal \\
& Sig sesudah diobati $0,079>0,05$ & \\
Uji Multikolinieritas & VIF variabel MBTE $1,099<10$ & Tidak terjadi multikolinieritas \\
& VIF variabel CSR $1,033<10$ & \\
& VIF variabel INSD $1,144<10$ & \\
& VIF variabel Komite Audit $1,028<10$ & \\
& VIF variabel TAG $1,046<10$ & \\
Uji Heteroskedastisitas & Sig. variabel MTBE $0,779>0,05$ & Tidak terjadi heteroskedastisitas \\
& Sig. variabel CSR $0,304>0,05$ & \\
& Sig. variabel INSD 0,114 $>0,05$ & \\
& Sig. variabel Komite Audit $0,715>0,05$ & \\
& Sig. variabel TAG $0,755>0,05$ & Tidak ada autokorelasi \\
Uji Autokorelasi & DW $=1,672$ & \\
& DU $=1,5955$ & \\
& $4-\mathrm{DU}=1,7851$ & \\
& $\mathrm{~d}_{\mathrm{U}}<\mathrm{d}<4-\mathrm{d}_{\mathrm{U}}$ & \\
\hline
\end{tabular}

Sumber: Output SPSS 
Muhammad Fariz Wiranoto. Pengaruh Growth Opportunity, Corporate Social Responsibility, Good Corporate Governance dan Keputusan Investasi terhadap Nilai Perusahaan (Studi pada Perusahaan Sektor Property, Real Estate \& Building Construction Periode 2013-2017)

Pada pengujian normalitas pertama dengan data yang diamati 245, diperoleh atau data tidak terdistribusi normal. Menindaklanjuti hal tersebut, maka dilakukan pengobatan data dengan menggunakan transformasi SQRT. Pengujian normalitas yang kedua setelah dilakukan transformasi dengan jumlah data yang diamati 110 dan diperoleh hasil data terdistribusi normal. Adapun pengujian asumsi klasik yang lain yaitu uji multikoliniritas, uji heteroskedastisitas dan uji autokorelasi semua dinyatakan terhindar dari gejala asumsi klasik.

\section{Uji Statistik F, Uji Statistik t dan Koefisien Determinasi}

Nilai signifikansi growth opportunity senilai 0,000 dan lebih rendah dari 0,05 serta nilai t hitung senilai 5,144 yang menggambarkan growth opportunity mempunyai pengaruh signifikan pada nilai perusahaan. Variabel corporate social responsibility memiliki nilai signifikansi senilai $0,385>0,05$ serta nilai t hitung senilai 0,873 yang menunjukkan bahwa corporate social responsibility secara signifikan tidak memberikan kontribusi pada nilai perusahaan. Variabel kepemilikan manajerial mempunyai nilai signifikansi $0,165>0,05$ serta nilai t hitung senilai -1,397 yang menunjukkan bahwa kepemilikan manajerial secara signifikan tidak memberikan kontribusi pada nilai perusahaan. Variabel komite audit mempunyai nilai signifikansi 0,688 > 0,05 dan nilai t hitung senilai 0,403 dan menggambarkan kepemilikan manajerial secara signifikan tidak berpengaruh pada nilai perusahaan. Variabel keputusan investasi memiliki nilai signifikansi 0,397 >0,05 dan nilai t hitung senilai $-1,772$ yang menunjukkan bahwa kepemilikan manajerial secara signifikan tidak berpengaruh terhadap nilai perusahaan.

Hasil hipotesis dengan uji $\mathrm{F}$, diketahui bahwa nilai tingkat signifikansi $\mathrm{F}_{\text {hitung }}$ sebesar 0,000 kurang dari nilai kritis $5 \%$ atau 0,05 . Nilai ini menujukkan bahwa secara simultan growth opportunity, corporate social responsbility, kepemilikan manajerial, komite audit dan keputusan investasi memberikan pengaruh yang signifikan terhadap nilai perusahaan.

Nilai Adjusted $R$ Square 0,182 dan diartikan kotribusi 18,2\% nilai perusahaan pada variabel independen secara keseluruhan. Total $81,8 \%$ penjelasan dapat dijabarkan dengan variabel lain, seperti struktur modal dan kinerja keuangan (Antari \& Dana, 2013 dan Hermuningsih, 2013).

\section{Pengaruh Growth Opportunity terhadap Nilai Perusahaan}

Hasil analisis data menunjukkan bahwa growth opportunity memberikan kontribusi pada nilai perusahaan sektor property, real estate \& building construction di BEI tahun 2013 sampai 2017. Besar kecilnya nilai growth opportunity yang diproksikan dengan MTBE memiliki pengaruh pada naik turunnya nilai perusahaan berdasarkan pengeluaran perusahaan di masa yang akan datang diharapkan akan menghasilkan return yang besar. Semakin tinggi nilai growth opportunity, akan berdampak pada semakin tinggi pula dana yang dibutuhkan oleh suatu perusahaan.

Hasil penelitian ini, perusahaan yang memiliki pengaruh growth opportunity akan mengalami kenaikan maupun penurunan dan dengan diikuti kenaikan penurunan nilai perusahaan yang diproksikan dengan PER. Selama periode penelitian ini terdapat beberapa nama perusahaan seperti, yang pertama BEST, perusahaan kedua adalah EMDE, perusahaan ketiga adalah MKPI, perusahaan keempat adalah MTLA, perusahaan kelima adalah PTPP, perusahaan keenam adalah RDTX, perusahaan ketujuh adalah TOTL, perusahaan kedelapan adalah WSKT. Perusahaan yang mangalami penurunan dan kenaikan growth opportunity terbukti juga diikuti kenaikan dan penurunan nilai perusahaan atau (PER).

Hasil penelitian sependapat dengan signaling theory, di mana perusahaan akan memberikan sinyal terkait peluang adanya pertumbuhan perusahaan kepada investor dengan menjanjikan tingkat pengembalian. Selaras dengan hasil penelitian Hermuningsih (2012) dan Adhitya Ananda \& Nugraha Ardana P (2018), di mana growth opportunity memiliki kontribusi atau pengaruh positif dan signifikan pada nilai suatu perusahaan. Pertumbuhan perusahaan dapat meningkatkan nilai perusahaan untuk mendapatkan keuntungan perusahaan sehingga investor lebih cenderung melihat keuntungan 
dari perusahaan dalam mengambil keputusan investasi, oleh karena itu growth opportunity mempengaruhi nilai perusahaan (Hermuningsih, 2012).

Hasil penelitian ini menjelaskan bahwa growth opportunity yang menggunakan proksi Market To Book Total Equity (MTBE) berpengaruh pada nilai perusahan. Growth opportunity mengandung implikasi agar kedepan perusahaan untuk selalu memperhatikan peluang pertumbuhan di masa yang akan datang, agar perusahaan dapat menghasilkan return yang lebih besar untuk lebih menarik investor menanamkan modalnya.

\section{Pengaruh CSR terhadap Nilai Perusahaan}

Berdasarkan hasil analisis data, diperoleh informasi bahwa Corporate Social Responsbility (CSR) tidak berpengaruh terhadap nilai perusahaan. Hasil penelitian ini menjelaskan bahwa kemampuan perusahaan dalam melaksanakan pengungkapan CSR tidak signifikan diakibatkan investor dalam negeri menjual atau membeli saham tidak memperhatikan keberlangsungan hidup perusahaan untuk kedepan, melainkan pada tingkat deviden yang diperolehnya (Setyawan, 2017).

Hasil penelitian ini, perusahaan yang memiliki nilai CSR tertinggi secara berturut-turut adalah DUTI dengan nilai GRI tahun 2013-2014 sebesar 49,4\%, tahun 2015 sebesar 51,9\%, dan tahun 2016-2017 sebesar 50,6\%. Perusahaan kedua adalah ASRI dengan nilai GRI tahun 2013 senilai 45,6\%, tahun 2014 senilai 46,8\%, tahun 2015 senilai 44,3\%, dan tahun 2016-2017 senilai 46,8\%. Perusahaan ketiga adalah RDTX dengan nilai GRI tahun 2013-2014 sebesar 38\%, tahun 2015 senilai 39,2\%, tahun 2016 senilai $41,8 \%$ dan tahun 2017 senilai 39,2\%. Dari 49 jumlah sampel yang diamati dalam penelitian selama periode 2013-2017, hanya ada satu perusahaan yaitu DUTI yang melaksanakan dan menyajikan informasi GRI lebih dari 50\%, sehingga masih belum memiliki pengaruh yang signifikan terhadap nilai perusahaan yang diprosikan dengan PER.

Menurut Veronica \& Wardoyo (2013) terdapat indikasi bahwa investor tidak perlu melihat pengungkapan CSR perusahaan, karena adanya jaminan seperti yang diatur dalam UU Perseroan Terbatas No. 20 Tahun 2007, di mana perusahaan melakukan tanggung jawab sosialnya dan pengungkapannya. CSR hanya sebagai bentuk dari dilakukannya peraturan yang berlaku, dan tidak mampu meningkatkan nilai perusahaan selain itu, tidak berpengaruhnya CSR terhadap nilai perusahaan dapat disebabkan karena masih minimnya perusahaan yang mengungkapkan CSR. Berdasarkan penelitian yang dilakukan oleh Agustine (2014), Setyawan (2017) dan Veronica \& Wardoyo (2013) menjelaskan bahwa Corporate Social Responsbility (CSR) masih belum dapat memberikan kontribusi pada peningkatan nilai perusahaan.

Hasil penelitian ini menunjukkan CSR tidak memberikan kontribusi pada nilai perusahaan, meskipun CSR mengandung implikasi masih belum menunjukkan pengaruh yang signifikan, untuk kedepan perusahaan diharapkan untuk selalu konsisten dalam menerapkan CSR. Pengungkapan CSR tidak hanya sekedar meningkatkan image perusahaan di mata stakeholder, namun pengungkapan CSR hingga saat ini sudah menjadi bagian dari isu global yang menjadi perhatian bagi pelaku bisnis.

\section{Pengaruh Kepemilikan Manajerial terhadap Nilai Perusahaan}

Hasil analisis data pada penelitian ini menunjukkan bahwa kepemilikan manajerial tidak berpengaruh terhadap nilai perusahaan, artinya besar kecilnya prosentase kepemilikan manajerial oleh pihak manajemen masih belum berdampak pada baik buruknya nilai perusahaan.

Pada penelitian ini, perusahaan yang memiliki nilai kepemilikan manajerial yang diproksikan dengan INSD tertinggi adalah RBMS pada tahun 2014-2017 dengan nilai INSD sebesar 0,503. Perusahaan kedua adalah FMII pada tahun 2016-2017 dengan nilai INSD sebesar 0,412. Perusahaan ketiga adalah BKDP pada tahun 2013 dengan nilai INSD sebesar 0,168. Dari 49 perusahaan sampel yang diteliti, sebanyak 25 perusahaan tidak memiliki kepemilikan manajerial atau sebanyak 51,02\%. Perusahaan yang memiliki kepemilikan manajerial yang diproksikan dengan INSD di setiap tahunnya tidak 
Muhammad Fariz Wiranoto. Pengaruh Growth Opportunity, Corporate Social Responsibility, Good Corporate Governance dan Keputusan Investasi terhadap Nilai Perusahaan (Studi pada Perusahaan Sektor Property, Real Estate \& Building Construction Periode 2013-2017)

memiliki perubahan yang signifikan atau jumlah kepemilikan manajerial cenderung sama. Hasil tersebut masih belum memiliki dampak yang signifikan pada peningkatan nilai perusahaan (PER).

Menurut Robin (2016), di mana perusahaan di Indonesia dalam sektor keuangan masih memiliki kepemilikan manajerial yang rendah, sehingga nilai perusahaan belum mengalami kenaikan. Rendahnya kepemilikan manajerial juga terjadi pada perusahaan sektor property, real estate \& building construction, di mana diketahui sebagian besar perusahaan tidak memiliki kepemilikan manajerial, hal ini dapat disebabkan minoritas seorang manajer masih belum dapat memotivasi pihak manajemen untuk bekerja lebih efektif dan efisien dalam meningkatkan kinerja perusahaan yang nantinya akan memiliki kontribusi di pemaksimalan nilai perusahaan (Thaharah \& Asyik, 2016). Selaras dengan penelitian Robin (2016), Gill \& Obradovich (2012) dan Thaharah \& Asyik (2016) menunjukkan kepemilikan manajerial masih belum memiliki dampak pada baik buruknya perusahaan.

Hasil penelitian ini diketahui kepemilikan manajerial masih belum memberikan kontribusi baik buruknya nilai perusahaan, hal tersebut mengandung implikasi bahwa perusahaan harus lebih memanfaatkan peran aktif dari kepemilikan manajerial dalam melakukan pengawasan kinerja manajemen adanya peningkatan kinerja manajemen akan memberikan kontribusi pada meningkatnya return, dan mampu menjadi daya tarik bagi calon investor dalam menanamkan modalnya.

\section{Pengaruh Komite Audit terhadap Nilai Perusahaan}

Pada penelitian ini perusahaan yang memiliki jumlah komite terbanyak adalah DILD pada tahun 2013 dengan jumlah komite audit 7 orang. Perusahaan kedua adalah ADHI pada tahun 2017 dengan jumlah komite audit 5 orang. Perusahaan ketiga adalah MTSM pada tahun 2013 dengan jumlah komite audit 4 orang. Perusahaan keempat adalah BCIP pada tahun 2013 dengan jumlah komite audit 4 orang. Perusahaan kelima adalah BKDP pada tahun 2017 dengan jumlah komite audit 4 orang. Dari 49 jumlah sampel yang telah diamati, menunjukkan bahwa sebagian besar perusahaan telah mengikuti Peraturan Otoritas Jasa Keuangan No 55 Tahun 2015 tentang pembentukan dan pedoman pelaksanaan kerja komite audit bab II pasal 4, di mana komite audit paling sedikit 3 orang dalam suatu perusahaan. Tetapi juga masih ada beberapa perusahaan dengan komite audit kurang dari 3 orang yaitu perusahaan ACST tahun 2014, ADHIN tahun 2014, BAPA tahun 2015-2016, GPRA tahun 2013-2015 dan PWON tahun 2013 di mana masing-masing perusahaan memiliki jumlah komite audit 2 orang. Jumlah komite audit atau keberadaan komite audit dalam perusahaan, hanya sebagai pada pemenuhan regulasi yang berlaku, dan komite audit masih belum melaksanakan tugas secara profesional.

Menurut Veronica \& Wardoyo (2013) keberadaan komite audit dalam suatu perusahaan masih belum menjadi jaminan bahwa perusahaan tersebut memiliki kinerja yang baik karena mengakibatkan keberadaan komite audit tidak jadi acuan pelaku pasar untuk pengambilan keputusan berinvestasi, dengan banyaknya komite audit dalam suatu perusahaan melaksanakan rapat menunjukkan profesionalitas dan keaktifannya dalam melakukan tugas dan tangungjawabnya dalam melaksanakan dan menjalankan pengendalian. Keberadaan komite audit dalam suatu perusahaan masih belum menunjukkan adanya perbaikan kinerja perusahaan dan memberikan efek negatif di perusahaan.

Menurut Setyawan (2017) tidak berpengaruhnya komite audit terhadap nilai perusahaan, dapat diakibatkan karena kurang optimalnya peran kerja dalam menjalankan fungsi pengawasan dan pengendalian manajemen perusahaan yang berdampak pada pertanggungjawaban manajemen perusahaan yang tidak transparan dan berdampak pada menurunnya kepercayaan pelaku modal sehingga terjadi penurunan nilai perusahaan. Hal tersebut sesuai penelitian Setyawan (2017) dan Veronica \& Wardoyo (2013) menjelaskan proporsi komite audit dalam suatu perusahaan masih belum menjamin nilai perusahaan akan membaik.

Analisis data yang telah dilakukan pada penelitian ini komite audit dalam menerapkan mekanisme corporate governance berpengaruh terhadap baik buruknya suatu nilai perusahaan. Komite audit mengandung implikasi di mana perusahaan harus memaksimalkan peran dalam upaya melakukan pengawasan dan melakukan penilaian untuk pertanggungjawaban manajemen suatu perusahaan 
terhadap pelaksanaan kegiatan secara profesional dan obyektif agar suatu perusahaan memiliki kinerja yang baik.

\section{Pengaruh Keputusan Investasi terhadap Nilai Perusahaan}

Berdasarkan hasil analisis data membuktikan keputusan investasi belum memberikan kontribusi pada nilai perusahaan, masih belum berpengaruhnya keputusan investasi pada nilai perusahaan, dapat diakibatkan karena masih belum tepatnya keputusan investasi yang diambil oleh pihak manajer perusahaan. Keputusan investasi yang dilakukan perusahaan, masih belum mampu meningkatkan nilai perusahaan.

Pada penelitian ini, perusahaan yang memiliki nilai keputusan investasi terbesar yang diproksikan dengan Total Asset Growth (TAG) adalah KPIG tahun 2016 dengan nilai TAG 11,559. Perusahaan kedua adalah OMRE tahun 2016 dengan nilai TAG 4,203. Perusahaan ketiga adalah DART tahun 2014 dengan nilai TAG sebesar 4,028. Perusahaan keempat adalah BIPP pada tahun 2013 dengan nilai TAG sebesar 2,147. Hasil 49 sampel yang diamati, diketahui sebagian besar perusahaan masih belum melaksanakan keputusan investasi yang berarti, di mana sebagian besar nilai TAG yang masih berada di bawah 1, yang artinya perusahaan masih belum melakukan keputusan ivestasi dalam skala yang besar. Keputusan investasi yang dilakukan perusahaan masih belum memiliki dampak yang signifikan pada penilaian perusahaan di mata pihak luar. Hal tersebut dikarenakan tingginya tingkat risiko investasi yang ditangggung di masa depan yang akan berakibat pada kesesuaian besaran investasi yang dilakukan sehingga mempengaruhi kepercayaan investor untuk menginvestasikan sejumlah dananya kepada perusahaan yang akan diinvestasi tersebut.

Sesuai penelitian Setiani (2013), pengambilan keputusan investasi tidak memberikan dampak di nilai perusahaan. Hal tersebut karena peningkatan risiko investasi yang ditanggung di waktu mendatang berakibat pada kesesuaian besar kecilnya investasi perusahaan, sehingga akan berdampak pada tingkat kepercayaan investor dalam menanamkan modalnya dalam perusahaan.

Keputusan investasi terbukti masih belum dapat mempengaruhi tinggi rendahnya nilai perusahaan. Hal ini mengandung implikasi bahwa perusahaan harus melakukan evalusi terkait pengeluaran dana yang bertujuan untuk investasi. Manajemen perusahaan harus menentukan investasi yang tepat, untuk mendapatkan return yang maksimal.

\section{KESIMPULAN}

Berdasarkan hasil penelitian diketahui growth opportunity, corporate social responsbility, kepemilikan manajerial, komite audit dan keputusan investasi memberikan pengaruh signifikan pada nilai perusahaan. Secara parsial, hanya varabel growth opportunity yang memberikan dampak pada nilai perusahaan. Variabel CSR masih belum berpengaruh terhadap nilai perusahaan dikarenakan hanya ada satu perusahaan yaitu DUTI yang melaksanakan dan menyajikan informasi GRI lebih dari lima puluh persen. Variabel kepemilikan manajerial masih belum memberikan dampak pada nilai perusahaan, dikarenakan sebagian besar perusahaan masih memiliki jumlah kepemilikan manajerialyang sama disetiap periodenya. Komite audit masih belum berpengaruh terhadap nilai perusahaan dikarenakan, masih beberapa perusahaan dengan jumlah komite audit tidak sesuai dengan Peraturan Otoritas Jasa Keuangan No 55 Tahun 2015, di mana komite audit dalam suatu perusahaan paling sedikit tiga orang. Variabel keputusan investasi masih belum berpengaruh terhadap nilai perusahaan, sebab dari jumlah sampel yang diamati, sebagian besar perusahaan masih belum melaksanakan keputusan investasi yang berarti, sebagian besar nilai TAG yang masih berada di bawah satu.

Bagi pihak manajemen perusahaan implikasi yang diharapkan adalah meningkatkan nilai perusahaan perlu memperhatikan growth opportunity. Bagi pihak investor implikasi yang diharapkan memberikan dampak pada keputusan investasi akan mempengaruhi nilai perusahaan, yang merupakan salah satu faktor yang sangat dipertimbangkan investor dalam berinvestasi. Bagi pada akademisi, penelitian ini 
Muhammad Fariz Wiranoto. Pengaruh Growth Opportunity, Corporate Social Responsibility, Good Corporate Governance dan Keputusan Investasi terhadap Nilai Perusahaan (Studi pada Perusahaan Sektor Property, Real Estate \& Building Construction Periode 2013-2017)

diharapkan dapat memberikan kontribusi positift terkait dengan growth opportunity, CSR, GCG dan keputusan investasi. Keterbatasan penelitian ini yaitu hanya menggunakan perusahaan sektor property, real estate \& building construction, sehingga masih belum mencerminkan keseluruhan perusahaan yang terdaftar di BEI. Untuk penelitian selanjutnya yang akan membahas tema serupa, diharapkan untuk menggunakan proksi pengukuran variabel lain untuk mendapatkan hasil yang lebih memuaskan dan periode penelitian terbaru.

\section{DAFTAR PUSTAKA}

Achmad, S. L., \& Amanah, L. (2014). Pengaruh Keputusan Investasi, Keputusan Pendanaan, Kebijakan Dividen Dan Kinerja Keuangan Terhadap Nilai Perusahaan. Jurnal Ilmu \& Riset Akuntansi Vol. 3 No. 9.

Ananda, N. A., \& Nugraha, I. N. (2016). Pengaruh Growth Opportunity Terhadap Nilai Perusahaan Melalui Struktur Modal (pada Perusahaan Sektor Property, Real Estate \& Building Construction yang Terdaftar di Bursa Efek Indonesia Tahun 2011-2014). Distribusi - Journal of Management and Business, 4(2), 15-28. https://doi.org/10.29303/distribusi.v4i2.11

Agustin, I. (2014). Pengaruh Corporate Social Responsibility Terhadap Nilai Perusahaan. Finesta, $1(2), 23-25$.

Anggraini, D. (2013). Pengaruh Good Corporate Governance Terhadap Nilai Perusahaan Pada Perusahaan Textile, Garment yang Terdaftar di Bursa Efek Indonesia (BEI) Periode 2009-2012. Jurnal Jurusan Akuntansi Fakultas Ekonomi Universitas Maritim Raja Ali Haji Tanjungpinang. https://jurnal.umrah.ac.id/wp-content/uploads/2013/09/Dina-Anggraini-090462201089.pdf

Antari, D. A., \& Dana, I. M. (2013). Pengaruh Struktur Modal, Kepemilikan Manajerial, Dan Kinerja Keuangan Terhadap Nilai Perusahaan. E-Jurnal Manajemen Universitas Udayana, 2(3), 255096.

Bidhari, S. C., Salim, U., \& Aisjah, S. (2013). Effect of Corporate Social Responsibility Information Disclosure on Financial Performance and Firm Value in Banking Industry Listed at Indonesia Stock Exchange. European Jornal of Business and Management Vol. 5, No. 18.

Brigham, E., \& Houston. (2010). Dasar-dasar Manajemen Keuangan Buku 1 (Edisi 11). Jakarta: Salemba Empat.

Gill, A., \& Obradovich, J. (2012). The impact of corporate governance and financial leverage on the value of American firms. International Research Journal of Finance and Economics ISSN 14502887 Issue 91. http://www.internationalresearchjournaloffinanceandeconomics.com

Herawati, T. (2013). Pengaruh Kebijakan Dividen, Kebijakan Hutang dan Profitabilitas Terhadap Nilai Perusahaan. Jurnal Manajemen. Vol.2 (2). 1-18.

Hermuningsih, S. (2012). Pengaruh Profitabilitas, Size Terhadap Nilai Perusahaan Dengan Sruktur Modal Sebagai Variabel Intervening. Jurnal Siasat Bisnis. 16(2), 232-242 https://doi.org/10.20885/jsb.vol16.iss2.art8

Hermuningsih, S. (2013). Pengaruh Profitabilitas, Growth Opportunity, Struktur Modal Terhadap Nilai Perusahaan Pada Perusahaan Publik di Indonesia. Buletin Ekonomi Moneter Dan Perbankan, 16(2), 127-148.

Jensen, M. C., \& Meckling, W. H. (1976). Theory of the firm: Managerial behavior, agency costs and ownership structure. Journal of Financial Economics. 3(4), 305-360. 
https://doi.org/10.1016/0304-405X(76)90026-X.

Kadek, A., \& Made S., S. (2016). Pengaruh Struktur Kepemilikan Saham, Struktur Modal Dan Profitabilitas Pada Nilai Perusahaan. Bisnis Universitas Udayana, 52(5), 201-218.

Martini, R. (2014). Pengaruh Kebijakan Utang Dan Profitabilitas Terhadap Nilai Perusahaan: Kebijakan Dividen Sebagai Variabel Pemoderasi. Jurnal Ilmu \& Riset Akuntansi, 3(2), 1-9.

Nisa. (2015). Pengaruh Keputusan Investasi, Keputusan Pendanaan, Dan Kebijakan Dividen Terhadap Nilai Perusahaan. Jurnal Manajemen Bisnis Indonesia, 6(1), 1-11.

Nyoman, N., Putu, G. M., \& Djazuli, A. (2014). Factors Affecting Firms Value of Indonesia Public Manufacturing Firms. International Journal of Business and Management Invention ISSN:23198028 Volume 3 Issue 2, 35-44.

Purwohandoko. (2017). The Influence of Firm's Size, Growth, and Profitability on Firm Value with Capital Structure as the Mediator: A Study on the Agricultural Firms Listed in the Indonesian Stock Exchange. International Journal of Economics and Finance. Vol. 9, No. 8 (2017), 103110. https://doi.org/10.5539/ijef.v9n8p103

Robin K., O. (2016). Pengaruh Tata Kelola Perusahaan terhadap Nilai Perusahaan pada Perusahaan Sektor Keuangan yang Terdaftar di BEI. Bina Ekonomi, Volume 20 Nomor 1, 1-22.

Setiani, R. (2013). Pengaruh Keputusan Investasi, Keputusan Pendanaan, Dan Tingkat Suku Bunga terhadap Nilai Perusahaan Pada Perusahaan Otomotif Yang Terdaftar Di Bursa Efek Indonesia. Jurnal Management, 2(1), 1-10.

Setyawan, B. (2017). Pengaruh Corporate Social Responsibility Dan Good Corporate Governance Terhadap Nilai Perusahaan (Studi Pada Sektor Pertambangan Di Bursa Efek Indonesia). Keberlanjutan, 2(1), 498-527. https://doi.org/10.32493/keberlanjutan.v2i1.y2017.p498-527

Sugiyono. (2012). Metode Penelitian Kuantitatif, Kualitatif Dan $R \& D$. Bandung: Alfabeta.

Thaharah \& Asyik. (2016). Pengaruh Mekanisme Corporate Governance Dan Kinerja Keuangan Terhadap Nilai Perusahaan LQ 45. Jurnal Ilmu Dan Riset Akuntansi Vol 5 No 2, 1-18.

Tjia, O., \& Setiawati, L. (2012). Effect of CSR Disclosure to Value of the Firm: Study for Banking Industry in Indonesia. World Journal of Social Sciences Issue. Pp, 2(6), 169-178.

Veronica, T. M., \& Wardoyo. (2013). Pengaruh Good Corporate Governance, CSR Dan Kinerja Keuangan Terhadap Nilai Perusahaan. Jurnal Dinamika Manajemen, 4(2), 132-149. http://journal.unnes.ac.id/nju/index.php/jdm 